\title{
Distribution of phytobenthosis in the presence of an invasive alga Caulerpa cylindracea on the Algerian west coast
}

\author{
MALIKA GHELLAI ${ }^{1}$, MOHAMMED EL AMINE BACHIR BOUIADJRA ${ }^{1}$, LAHOUARI DAHLOUM ${ }^{2, *}$, \\ AHMED MEGHARBI ${ }^{1}$, BENABDALLAH BACHIR BOUIADJRA ${ }^{3}$ \\ ${ }^{1}$ Ahmed Zabana University. Relizane, BP 48000, Algeria \\ ${ }^{2}$ Department of Agronomy, Abdelhamid Ibn Badis University. Av. Hamadou Hossine, 27000, Mostaganem, Algeria. \\ Tel.: +213-672515273, Fax.: +213-45416827, `email: dahloumhouari@gmail.com \\ ${ }^{3}$ Laboratoire des Sciences et Techniques de Production Animale, Abdelhamid Ibn Badis University. Av. Hamadou Hossine, 27000, Mostaganem, Algeria
}

Manuscript received: 17 October 2021. Revision accepted: 28 November 2021.

\begin{abstract}
Ghellai M, Bachir-Bouiadjra MEA, Dahloum L, Megharbi A, Bachir-Bouiadjra B. 2021. Distribution of phytobenthosis in the presence of an invasive alga Caulerpa cylindracea on the Algerian west coast. Biodiversitas 22: 5644-5653. We have targeted and followed the speed of expansion of Caulerpa cylindracea Sonder 1845 through visiting sixteen sites on the Algerian west coast, out in five provinces which are; Tlemcen, Aïn Témouchent, Oran, Mostaganem and Chlef, where it was listed in eight stations; the coastal lines of Oran and Mostaganem, and in a single station in the province of Aïn Témouchent. The phytosociological surveys were established, made it possible to see the frequency of each identified taxon, mentioning a high degree of disturbance in the appearance of benthic macrophytes regarding the dominance of the invasive species. The calculation of the Shannon index and equitability identify the ecological state of the sites, varies from average $\left(\mathrm{H}^{\prime}\right.$ around 3.29 for sites little and not invaded by Caulerpa) to poor $\left(\mathrm{H}^{\prime}: 1.74\right.$ for Salamandre), with low macrophytic biodiversity $(0.4 \leq \mathrm{E} \leq 0.64)$. The calculation of the Caulerpa racemosa (ICar) index on sandy to rocky substrates with algae does not appear to be a limiting factor for the spread of the invasive species. The previous analyses were validated statistically using Factorial correspondence analysis (FCA), Ascending hierarchical classification (AHC), Principal component analysis (PCA), justifying the unbalanced state according to the degrees of pollution.
\end{abstract}

Keywords: Algerian, Caulerpa cylindracea, phytosociological

\section{INTRODUCTION}

Marine organisms produce a wide variety of natural products, often unique and essential to their survival and ecological performance (Avila et al. 2018; Blunt et al. 2018; Puglisi and Becerro 2018; Carroll et al. 2019). The diversity of algae varies in size and composition and contains a wide variety of species that are widely distributed in different marine sites depending on their adaptability (Kalasariya et al. 2020). Among the natural marine resources, they represent one of the richest sources of natural antioxidants (Khalid et al. 2018). Indeed, algae are known for their antioxidant properties given their richness in bioactive compounds such as polyphenols, terpenoids, alkaloids, saponins, tannins and steroids (Kumar et al. 2019; Oucif et al. 2017; Oucif 2018; Ragunathan et al. 2019). The effects of biological invasions on algal biodiversity are often equivocal (Gribben et al. 2018) with positive and negative impacts on indigenous assembly depending on the geographical context and the temporal and spatial scales of observation (Balestri et al. 2018; Tamburello et al. 2015). Among these bio-invasions, we name Caulerpa cylindracea, exhibiting a strongly invasive behavior during its colonization (Manconi et al. 2020), of Australian origin (Ghellai 2021). However, it has received much less attention than its congeneric species despite being considered one of the most threatening invasions of the Mediterranean Sea (Piazzi et al. 2016). In addition, its presence could have a positive effect on meiofaunal abundance wherever sediment deposition rates are low (Rizzo et al. 2020). From another part, the species presents a source of bioactive compounds of nutritional and pharmacological interest (Belkacemi et al. 2020). C. cylindracea has settled in several sites on the Algerian coast (Bentaallah and Kerfouf 2013). Research on the expansion and control of this algae has spread over the Algerian west coast by monitoring Bachir Bouiadjra, who has reported its presence on several stations; two sites on the Mostaganémoise coast; Stidia et Salamandre (Bachir Bouiadjra et al. 2010), and the Arzew site in the city of Oran (Chahrour 2013), as well as on the Kristel coast in 2013, then in Bousfer in 2015 in Oran (Hussein and Bensahla 2019).

This study aims to study the degree and speed of expansion of the invasive species $C$. cylindracea along the Algerian west coast, using index methods and the statistical tool by signaling the danger of its expansion as well that by predicting its future proliferation to the challenge of other benthic macrophytes of ecological and economic interest.

\section{MATERIALS AND METHODS}

\section{Choice of study sites}

We surveyed 16 affected sites in 5 coastal provinces of western Algeria (Figure 1, Table 1). 


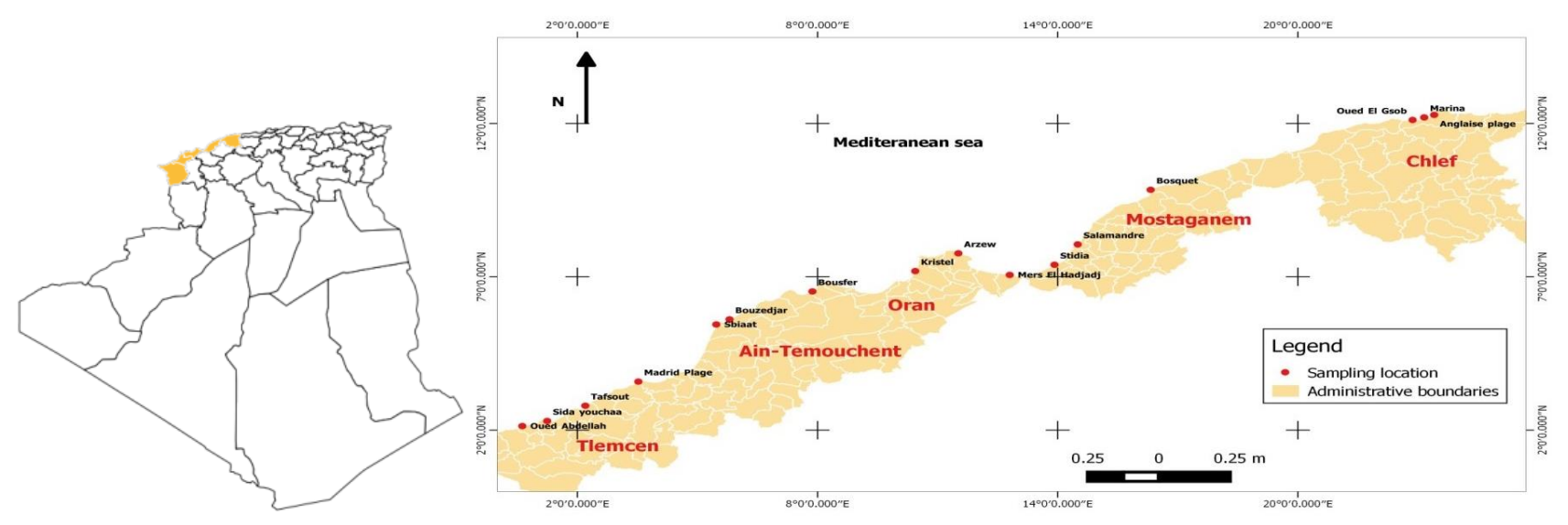

Figure 1. Map indicating sampling site in Algeria (Google Earth)

Table 1. Geographic coordinates of the prospected sites

\begin{tabular}{|c|c|c|}
\hline Province & $\begin{array}{c}\text { Sampling } \\
\text { location }\end{array}$ & Geographical localization \\
\hline \multirow[t]{3}{*}{ Tlemcen } & Oued Abdellah & $35^{\circ} 05^{\prime} 38^{\prime \prime} \mathrm{N}, 1^{\circ} 51^{\prime} 37^{\prime \prime} \mathrm{W}$ \\
\hline & Sidna Youchaa & $35^{\circ} 11^{\prime} 81^{\prime \prime} \mathrm{N}, 1^{\circ} 77^{\prime} 95^{\prime \prime} \mathrm{W}$ \\
\hline & Tafsout & $35^{\circ} 10^{\prime} 35^{\prime \prime} \mathrm{N}, 1^{\circ} 39^{\prime} 18^{\prime \prime} \mathrm{W}$ \\
\hline Ain & Plage de Madrid & $35^{\circ} 18^{\prime} 08^{\prime \prime} \mathrm{N}, 1^{\circ} 23^{\prime} 01^{\prime \prime} \mathrm{W}$ \\
\hline \multirow[t]{2}{*}{ Témouchent } & Sbeaat & $35^{\circ} 18^{\prime} 26.1^{\prime \prime} \mathrm{N}, 1^{\circ} 8^{\prime} 32.825^{\prime \prime} \mathrm{W}$ \\
\hline & Bouzedjar & $35^{\circ} 34^{\prime} 28^{\prime \prime} \mathrm{N}, 1^{\circ} 10^{\prime} 01^{\prime \prime} \mathrm{W}$ \\
\hline \multirow[t]{4}{*}{ Oran } & Bousfer & $35^{\circ} 43^{\prime} 36^{\prime \prime} \mathrm{N}, 0^{\circ} 51^{\prime} 0^{\prime \prime} \mathrm{W}$ \\
\hline & Kristel & $35^{\circ} 49^{\prime} 34^{\prime \prime} \mathrm{N}, 0^{\circ} 29^{\prime} 00^{\prime \prime} \mathrm{W}$ \\
\hline & Arzew & $35^{\circ} 51^{\prime} 01^{\prime \prime} \mathrm{N}, 0^{\circ} 19^{\prime} 04^{\prime \prime} \mathrm{W}$ \\
\hline & Mers El Hadjadj & $35^{\circ} 47^{\prime} 00^{\prime \prime} \mathrm{N}, 0^{\circ} 10^{\prime} 00^{\prime \prime} \mathrm{W}$ \\
\hline \multirow[t]{3}{*}{ Mostaganem } & Stidia & $35^{\circ} 50^{\prime} 00^{\prime \prime} \mathrm{N}, 0^{\circ} 00^{\prime} 00^{\prime \prime}$ \\
\hline & Salamandre & $35^{\circ} 56^{\prime} 00^{\prime \prime} \mathrm{N}, 0^{\circ} 05^{\prime} 00^{\prime \prime} \mathrm{E}$ \\
\hline & Bosquet & $36^{\circ} 06^{\prime} 00^{\prime \prime} \mathrm{N}, 0^{\circ} 20^{\prime} 00^{\prime \prime} \mathrm{E}$ \\
\hline \multirow[t]{3}{*}{ Chlef } & Oued Elgsob & $36^{\circ} 30^{\prime} 16^{\prime \prime} \mathrm{N}, 1^{\circ} 15^{\prime} 27^{\prime \prime} \mathrm{E}$ \\
\hline & Marina & $36^{\circ} 30^{\prime} 19^{\prime \prime} \mathrm{N}, 1^{\circ} 14^{\prime} 09^{\prime \prime} \mathrm{E}$ \\
\hline & Anglaise & $36^{\circ} 31^{\prime} 35^{\prime \prime} \mathrm{N}, 1^{\circ} 19^{\prime} 24^{\prime \prime} \mathrm{E}$ \\
\hline
\end{tabular}

\section{Plant material}

At each station, the sampling of benthic macrophytes present took place over a minimum area of $20 \mathrm{~cm}^{2}$ in order to obtain the mode of arrangement between the different species of plants in the presence or absence of our taxon of research interest $C$. cylindracea, regarding its proliferation in our coastline gaining important areas in benthic environments hindering the integration of other species of economic and ecological interest.

\section{Phytosociological study}

\section{Frequency study}

The present study identifies the phytosociological behavior towards different species of benthic macrophytes. We have calculated the frequency of each taxon, in order to establish the presence degree of the latter in collaboration with the others in general and for the case of $C$. cylindracea in particular. In a survey divided into squares, the frequency of a species, expressed as a percentage, is the ratio of the number of squares where it is present over the total number of squares (Boudouresque 1971). It is given by the following formula:

$$
\mathrm{F}=(\mathrm{A} / \mathrm{N}) \times 100
$$

The results obtained are classified according to the intervals of values to identify the appearance of which taxon in which the following taxon: If $0.5<\mathrm{F}<1.9$, the species is considered rare, if $5<\mathrm{F}<29.5$, the species is designated as present, if $30<\mathrm{F}<49.5$, the species is common, if $50<\mathrm{F}<79.5$, the species is frequent in this environment, and if $80<\mathrm{F}<100$ we are within the limit of having very frequent species.

\section{Shannon index $\left(H^{\prime}\right)$}

One of the indices derived from the information theory, and the most used in the population's study is given by the expression of Shannon and Weaver (1949):

$$
\begin{aligned}
& \mathrm{H}^{\prime}=-\Sigma\left[\mathrm{Pi} \times \log ^{2} \mathrm{Pi}\right] \\
& \mathrm{Pi}(\text { relative overlap of species } \mathrm{i})=\mathrm{Ri} / \mathrm{Rt}
\end{aligned}
$$

Where, Ri: Recovery of species I; Rt: Total recovery.

According to the obtained values of H', we can classify the ecological state of the stations according to the following intervals of the thresholds of $\mathrm{H}^{\prime}$ designated by Simboura and Zenetos (2002): If $0<\mathrm{H}^{\prime} 1.5$ : we are in a very polluted site with a bad ecological state; If $1.5<\mathrm{H}^{\prime} \leqslant 3$ : the site is heavily polluted with a poor ecological status; If $3<\mathrm{H}^{\prime} \leqslant 4$ : the site is moderately polluted, the ecological state is designated as medium; If $4<\mathrm{H}^{\prime} \leqslant 5$ : a transition zone with a good ecological status; If $\mathrm{H}^{\prime}>5$ : we are in a reference site with very good ecological status.

\section{The equity index (E) (fairness index)}

To compare the structure of several populations, we use the Regularity (Frontier and Pichod-Viale 1991) defined as the ratio between effective diversity of the community and its maximum theoretical diversity: 


\section{$E=H^{\prime} / \log 2 T$}

Where, T: total number of species recorded.

When this tends towards 1 , it provides information on an even distribution of dominances between all the species listed; the specific recoveries are inequitably distributed when $\mathrm{E}$ tends towards 0 .

\section{The Caulerpa cylindracea Landscape Index; ICar}

The ICar landscape index was defined by Cariou et al. (2013) based on 4 criteria: (1) According to the qualification of the colonized substrate; either of ( Va) mud, (Sa) sand, (Ro) rock, (RA) rock with algae, $(\mathrm{Po})$ posidonia, (MP) dead matte of posidonia or (CM) coralligenousmaërl); (2) For each site, the area of the colonized zone is qualified in 4 categories either an absence of $C$. racemosa (S0), or a colonized spots less than $1 \mathrm{~m}^{2}$ (S1), or a colonized spots greater than $1 \mathrm{~m}^{2}$ (S2), or a continuous meadow (S3); (3) For each site, the algal cover is qualified in 5 categories: either an absence of $C$. racemosa $(\mathrm{C} 0)$; either a very irregular distribution of the algae at very low density with a number of fronds easy to count $(\mathrm{C} 1)$; either a greater density of the algae but with an irregular distribution (C2); either a relatively high and regular density with the crawling part (stolon) in one or even two layers (C3); or a significant and regular density with the crawling part in several layers (stolons overlapping) (C4); (4) For each site, the diver's experience is qualified in 3 categories: either he has never seen the Caulerpa (P1), or he has already observed certain cover signs of $C$. racemosa (P2), or he has already observed all the cover indices in $C$. racemosa $(\mathrm{P} 3)$. Therefore, this results in an 8-character code for each site studied.

The results obtained are statistically validated using $R$ software, according to Correspondence Factor Analysis (CFA), Ascending Hierarchical Classification (AHC), and Principal Component Analysis (PCA).

\section{RESULTS AND DISCUSSION}

\section{Caulerpa cylindracea frequencies}

Our prospecting carried out on the search for the invasive taxon $C$. cylindracea on sixteen stations of the Algerian west coast allowed us first of all to record the presence of this taxon in only eight stations among the others, listing from the west to the east; the site of Sbeaat, Bousfer, Kristel, Arzew, Mers El Hadjadj, Stidia, Salamandre, and Bosquet. The overall survey presented in Figure 2 summarizes and groups the status of each station studied with regard to the presence, absence, and estimated frequency of the invasive taxon $C$. cylindracea.

From the frequencies of $C$. cylindracea established in different sites, we could mention the designation of its expansion according to; Frequent and Common at the level of the most affected sites citing; Salamandre, Stidia, Arzew and Bousfer. It is present for the two moderately invaded sites, which are Mers El Hadjadj and Kristel, as well as rare for the sites weakly affected by the invasion, which are Bosquet and Sbeaat.

Bachir (2012), confirmed the critical situation observed at the two stations such as Salamandre and Stidia due to the colonization of $C$. cyclindracea, as well as a weak propagation at the level of the Bosquet site was reported in 2010. Moreover, it was first reported on the Arzew golf course in 2010, and then in 2013 (Bachir et al. 2010b; Chahrour 2013), as well as on the Kristel coast in 2013, then in Bousfer in 2015 (Hussein and Bensahla 2019).

\section{The Diversity index, Shannon index H', and Fairness E}

The Shannon H' index gives a direct appreciation of the mediums. It confirms what is said before about the expansion of the invasive algae, giving for the most affected places the designation of poor concerning the ecological state justified as disturbed, this is for the following sites (Figure 3); Salamandre with a strong spread of the invasive taxon influencing the quality of the marine environment recording the lowest value (H': 1.74) in order to subsequently have a low value for the fairness index $(\mathrm{E}$ : 0.4 ), then the stations strongly affected by $C$. cylindracea including; Stidia, Bousfer, Arzew, Mers El Hadjadj, and Kristel (H': 2.09, 2.16, 2.19, 2.48, and 2.6, respectively) and which are reported as heavily polluted environments, recording $\mathrm{E}$ values ranging from 0.42 to 0.5 .

The prospecting carried out at the Stidia and Salamandre stations made it possible to record low values of H', varying from 1.32 to 1.44 , faithfully followed by a fairness index (E) oscillating between 0.73 to 0.76 . However, these stations are heavily affected by direct industrial, domestic and urban discharges, and water without prior treatment, thus generating ever-increasing pollution, inevitably affecting the algal community in its diversity (Bachir 2012).

The Sbeaat and Bosquet sites also recorded slightly elevated H' values of 2.74 and 2.96, respectively, but still designating sites in a state of disturbance, with $E$ values of 0.57 and 0.6, respectively. Bachir (2012), reported that the Bosquet station, which is relatively spared from the pollution of various origins, presents indices of diversity and fairness slightly higher. However, vigilance must be put in this area hence the need to consider appropriate measures before it is too late.

For the three stations visited in the province of Tlemcen, the two stations of Aïn Témouchent (Madrid and Bouzedjar), and the last three stations of Chlef, not present the expansion of the studied invasive taxon, allowing us to consider them as moderately polluted sites, with an ecological status designated as medium, showing values $\mathrm{H}^{\prime}$ between 3.01 and 3.29 (case of Sidna Youchaa and the plage Anglaise stations as retained examples), revealing visibly higher values of $\mathrm{E}$ compared to the previous cases, varying between 0.60 and 0.64 . Indeed, the diversity index $\left(H^{\prime}\right)$ shows fairly high values in relatively clean stations, as well as lower values in relatively polluted or unstable stations (Chabane 2019). 


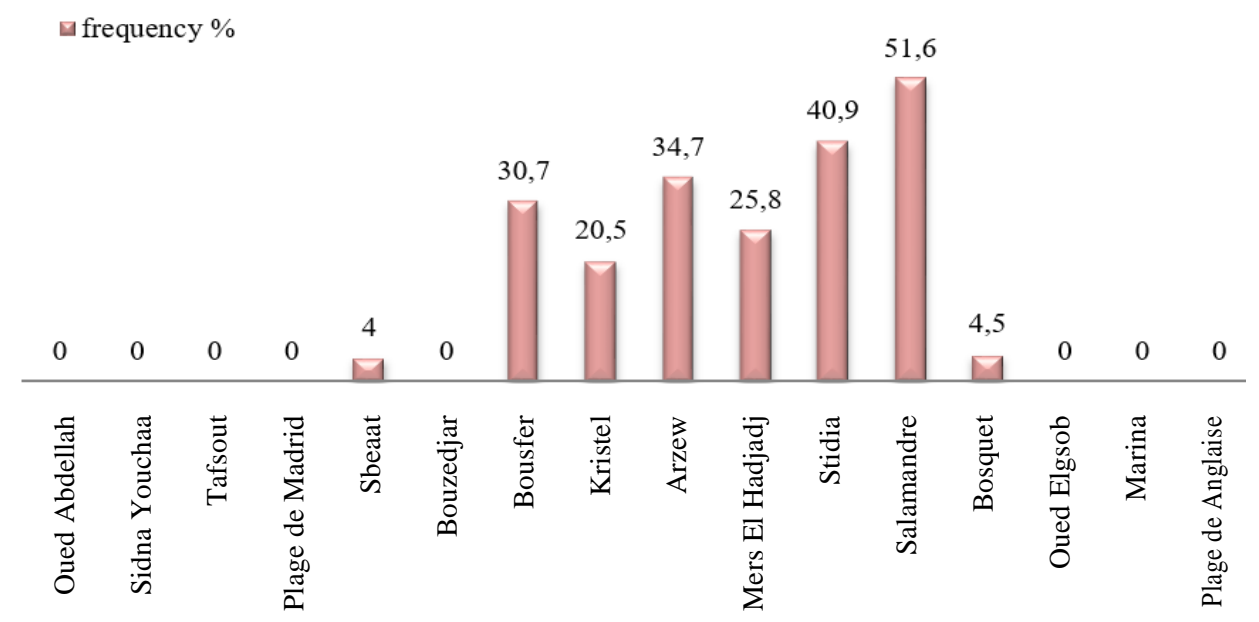

Figure 2. The frequencies of $C$. cylindracea in different stations

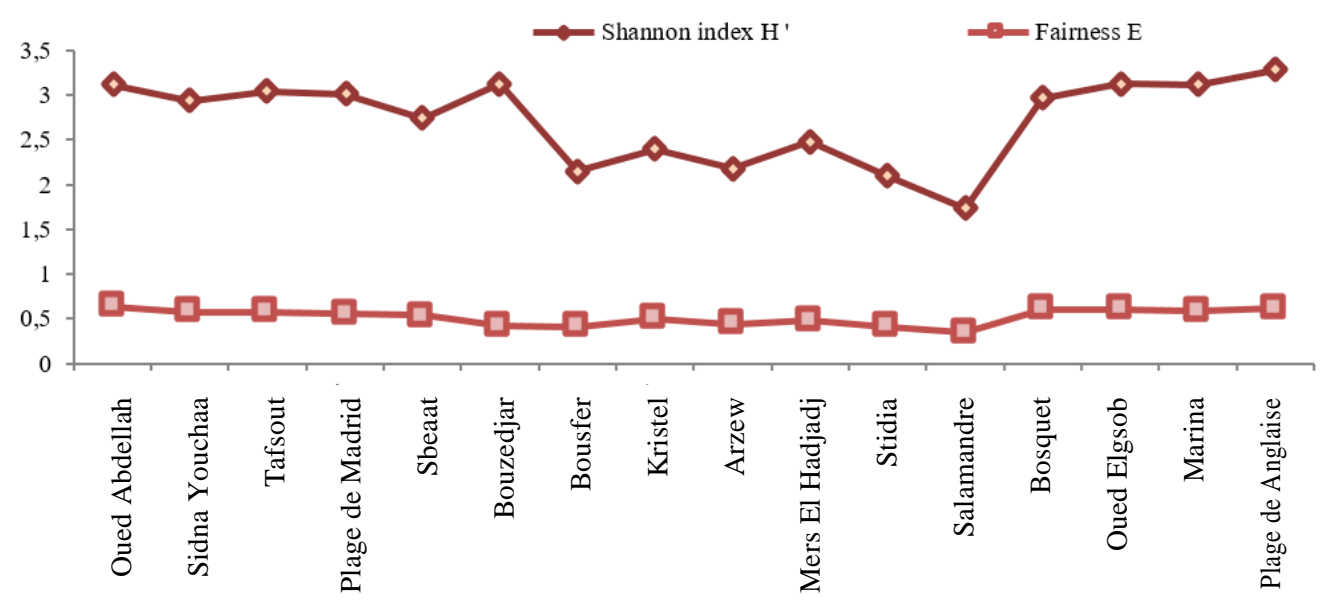

Figure 3. Axis for the diversity index $H$ 'and equity axis E calculated for all stations

Study of the Caulerpa racemosa Landscape Index; ICar

The exploration results of identifying the visited areas through the Caulerpa racemosa index; ICar is summarized in Table 2. ICar was created and applied by Cariou et al. (2013), for the first time in 2011 and 2012, in the Bay of La Revellata (France), over a wide range of depths ranging from 3 to $42 \mathrm{~m}$. The ICar landscape index could be applied throughout the Mediterranean. This simple methodology allows qualifying the different zones colonized by Chlorobiont. It also makes it possible to monitor the spatiotemporal evolution of invasive algae's distribution (Cariou et al. 2013). The latter covered neither the silt nor the coralligenous, in which it was present on all the other categories of substrates encountered in the studied area (Cariou et al. 2013).

First, the Oued Abdellah, Sidna Youchaa, Tafsout, Madrid and Bouzedjar sites, located in the extreme west of Algeria, as well as the rest of the stations located in the east of the study area; Oued Elgsob, Marina and the plage Anglaise, are classified as unaffected by the invasive species $C$. cylindracea. The substrates of its studied sites vary from rocky with algae to Sandy.
The ICar study gives us an appreciation of the areas nature affected by $C$. cylindracea, even the nature of the substrate, varying from Sandy to Rocky with algae, as well as a small-scale surface qualification, giving the impression of having spots of less than $1 \mathrm{~m}^{2}$, with a very irregular distribution, for sites with low colonization, and spots greater than $1 \mathrm{~m}^{2}$ with relatively large distribution, for other sites. In the Salamandre station, continuous meadows with a high density of these invasive algae are found.

The type of substrate does not appear to be a limiting factor in the expansion of $C$. cylindracea, it colonizes Posidonia's dead matte, detritic coast, rocky and sandy substrates, and even the Posidonia's healthy herbarium (Cariou et al. 2013; Gobert and Richir 2019). This index is thought to be applicable and usable by the greatest number of marine biologists, managers of the coastal environment or recreational divers. This is made possible through the dissemination of a brochure identifying the status of substrate colonization by Caulerpa (Gobert and Richir 2019). 


\section{Statistical study}

We established the statistical tests on the basis of Table 3 summarizing the frequencies of recent species at the different study sites.

\section{Correspondence Factor Analysis (CFA)}

In order to highlight certain factors which react to the distribution of benthic macrophytes, regarding the invasion of $C$. cylindracea, factorial correspondence analysis is carried out on a matrix of 21 species, distributed in sixteen sampling stations (Figures 4 and 5).

The F1-F2 plan shows in its negative side, the tolerant species of polluted water, namely respectively Sargassum vulgare, Cystoseira baccata (-2.5), as well as Caulerpa prolifera (-1.48), and C. cylindracea (-1.21), designated in the pollution gradient, followed by Cystoseira stricta and Codium fragile (-1.78); this axis therefore represents through its negative side, a gradient in the intensity of water agitation (Figure 4).

The factorial plane F1-F3 is explained in its negative side by photophile species, namely particularly Jania rubens $(-1.61)$, Caulerpa prolifera $(-1.31)$. The positive side does not explain any gradient. This axis therefore represents, through its negative side, a gradient of brightness. Overall, figures 4 and 5 explain that the expansion of the invasive $C$. cylindracea species is not limited by the various factors mentioned above, depending on the gradients of pollution, turbidity, and light (Figure 5).

Table 2. Prospecting data according to ICar in the prospected sites

\begin{tabular}{llccc}
\hline \multicolumn{1}{c}{ Site } & \multicolumn{1}{c}{ Geographical location } & Depth (m) & Year & ICar \\
\hline Oued Abdellah & $35^{\circ} 05^{\prime} 38^{\prime \prime} \mathrm{N}, 1^{\circ} 51^{\prime} 37^{\prime \prime} \mathrm{W}$ & 2 & 2020 & RA S0 C0 P1 \\
SidnaYouchaa & $35^{\circ} 11^{\prime} 81^{\prime \prime} \mathrm{N}, 1^{\circ} 77^{\prime} 95^{\prime \prime} \mathrm{W}$ & $0.5-1$ & 2020 & RA S0 C0 P1 \\
Tafsout & $35^{\circ} 10^{\prime} 35^{\prime \prime} \mathrm{N}, 1^{\circ} 39^{\prime} 18^{\prime \prime} \mathrm{W}$ & 1.5 & 2020 & RA S0 C0 P1 \\
Plage de Madrid & $35^{\circ} 18^{\prime} 08^{\prime \prime} \mathrm{N}, 1^{\circ} 23^{\prime} 01^{\prime \prime} \mathrm{W}$ & $0.5-1$ & 2019 & Sa S0 C0 P1 \\
Sbeaat & $35^{\circ} 18^{\prime} 26^{\prime \prime} \mathrm{N}, 1^{\circ} 8^{\prime} 32^{\prime \prime} \mathrm{W}$ & $0.5-1$ & 2019 & Sa S1 C1 P2 \\
Bouzedjar & $35^{\circ} 34^{\prime} 28^{\prime \prime} \mathrm{N}, 1^{\circ} 10^{\prime} 01^{\prime \prime} \mathrm{W}$ & $0.5-1$ & 2019 & Sa S0 C0 P1 \\
Bousfer & $35^{\circ} 43^{\prime} 36^{\prime \prime} \mathrm{N}, 0^{\circ} 51^{\prime} 0^{\prime \prime} \mathrm{W}$ & $1-1.5$ & 2019 & RA S2 C3 P2 \\
Kristel & $35^{\circ} 49^{\prime} 34^{\prime \prime} \mathrm{N}, 0^{\circ} 29^{\prime} 00^{\prime \prime} \mathrm{W}$ & $1-1.5$ & 2019 & Sa S2 C2 P2 \\
Arzew & $35^{\circ} 51^{\prime} 01^{\prime \prime} \mathrm{N}, 0^{\circ} 19^{\prime} 04^{\prime \prime} \mathrm{W}$ & $1-1.5$ & 2019 & RA S2 C3 P2 \\
Mers El Hadjadj & $35^{\circ} 47^{\prime} 00^{\prime \prime} \mathrm{N}, 0^{\circ} 10^{\prime} 00^{\prime \prime} \mathrm{W}$ & $1-1.5$ & 2019 & Sa S2 C3 P2 \\
Stidia & $35^{\circ} 50^{\prime} 00^{\prime \prime} \mathrm{N}, 0^{\circ} 00^{\prime} 00^{\prime \prime}$ & $0.5-1$ & 2019 & RA S2 C3 P2 \\
Salamandre & $35^{\circ} 56^{\prime} 00^{\prime \prime} \mathrm{N}, 0^{\circ} 05^{\prime} 00^{\prime \prime} \mathrm{E}$ & $0.5-1$ & 2019 & RA S3 C4 P2 \\
Bosquet & $36^{\circ} 06^{\prime} 00^{\prime \prime} \mathrm{N}, 0^{\circ} 20^{\prime} 00^{\prime \prime} \mathrm{E}$ & $1-1.5$ & 2019 & RA S1 C1 P2 \\
Oued Elgsob & $36^{\circ} 30^{\prime} 16^{\prime \prime} \mathrm{N}, 1^{\circ} 15^{\prime} 27^{\prime \prime} \mathrm{E}$ & $0.5-1$ & 2018 & Sa S0 C0 P1 \\
Marina & $36^{\circ} 30^{\prime} 19^{\prime \prime} \mathrm{N}, 1^{\circ} 14^{\prime} 09^{\prime \prime} \mathrm{E}$ & $0.5-1$ & 2018 & RA S0 C0 P1 \\
Anglaise & $36^{\circ} 31^{\prime} 35^{\prime \prime} \mathrm{N}, 1^{\circ} 19^{\prime} 24^{\prime \prime} \mathrm{E}$ & $0.5-1$ & 2018 & Sa S0 C0 P1 \\
\hline
\end{tabular}

Table 3. Frequencies (\%) of species listed in the different stations

\begin{tabular}{|c|c|c|c|c|c|c|c|c|c|c|c|c|c|c|c|c|}
\hline Listed species / station & 1 & 2 & 3 & 4 & 5 & 6 & 7 & 8 & 9 & 10 & 11 & 12 & 13 & 14 & 15 & 16 \\
\hline$\overline{\text { Carradoriella elongata (Car_elo) }}$ & & & & & & & & & & & 4.5 & & & 6.6 & & \\
\hline Caulerpa cylindracea (Cau_cyl) & & & & & 4 & & 30.7 & 20.5 & 35.7 & 25.8 & 40.9 & 51.6 & 4.5 & & & \\
\hline Caulerpa prolifera (Cau_pro) & & & & & & & & & & 11.7 & 4.5 & & & & & \\
\hline Cladophora laetevirens (Kla_lae) & 22.7 & & 15 & 12.5 & & & & & & & & & & 16.6 & 12.5 & 12.5 \\
\hline Codium fragile (Cod_fra) & & & & & & & & 17.6 & & & & & & & & \\
\hline Corallina officinalis (Cor_off) & 13.6 & 25 & 15 & 12.5 & 12 & 15 & & 5.8 & 8.8 & & & & & & 8.3 & 8.3 \\
\hline Cystoseira baccata (Cys_bac) & & & & & & & & & & & 13.6 & & & & & \\
\hline Cystoseira compressa (Cys_com) & 22.7 & 25 & & & & & 10 & & & & & 19.3 & & 16.6 & & \\
\hline Cystoseira stricta (Cys_str) & & & & 25 & & & & 17.6 & & & & & 30 & & & \\
\hline Dictyopteris membranacea (Dic_mem) & & & & & & & 13.3 & 11.7 & & & & & 2.5 & & & \\
\hline Dictyota dichotoma (Dic_dic) & 13.6 & & & 8.3 & & 10 & & 11.7 & 14.2 & 19.3 & & & & & & 8.3 \\
\hline Ellisolandia elongata & & 10 & 15 & & & 10 & 10 & & & & & & & & & \\
\hline Hypnea musciformis ( & & 10 & 10 & & 2 & 10 & 1.7 & & & & & & 4.5 & 6.6 & 8.3 & 16.6 \\
\hline Jania rubens (Jan_ru & 9 & & & 8.3 & & & & & 14.2 & 19.3 & & & & & & \\
\hline Padina pavonica (Pad_pav) & 18 & 25 & 15 & 12.5 & & 15 & & 11.7 & 14.2 & 9.6 & 6.8 & 9.6 & 15 & 10 & 12.5 & 12.5 \\
\hline Posidonia oceanica (Pos_c & & & & & & & & & & & 4.5 & 6.4 & 4.5 & 16.6 & 12.5 & 12.5 \\
\hline Sargassum & & & & & & & & & & & 13.6 & & & & & \\
\hline Ulva & & & 15 & 12.5 & 20 & 15 & 10 & & & & 6.8 & 6.4 & 25 & 13.3 & 16.6 & 12.5 \\
\hline Ulva intestir & 13.6 & 20 & 15 & & 20 & 15 & 10 & & 14.2 & & & & & & 12 & 12.5 \\
\hline Ulva & 18 & 15 & 25 & 20.8 & 20 & 25 & 10 & 11.7 & 14.2 & 12.9 & 6.8 & 6.4 & 20 & 13.3 & 16.6 & 12.5 \\
\hline Ulva rigida (Ulv_rig) & 18 & 15 & 25 & 20.8 & 20 & 25 & 10 & 11.7 & & 9.6 & & & 20 & 13.3 & 16.6 & 12.5 \\
\hline
\end{tabular}

Note: 1: Oued Abdellah (OA); 2: Sidna youchaa (SY); 3: Tafsout (TF); 4: Madrid (MD); 5: Sbeaat (SB); 6: Bouzedjar (BZ); 7: Bousfer (BS); 8: Kristel (KR); 9: Arzew (AZ); 10: Mers El Hadjadj (MH); 11: Stidia (SD); 12: Salamandre (SM); 13: Bosquet (BQ); 14: Oued Elgsob (OG); 15: Marina (MN); 16: Plage Anglaise (AG) 


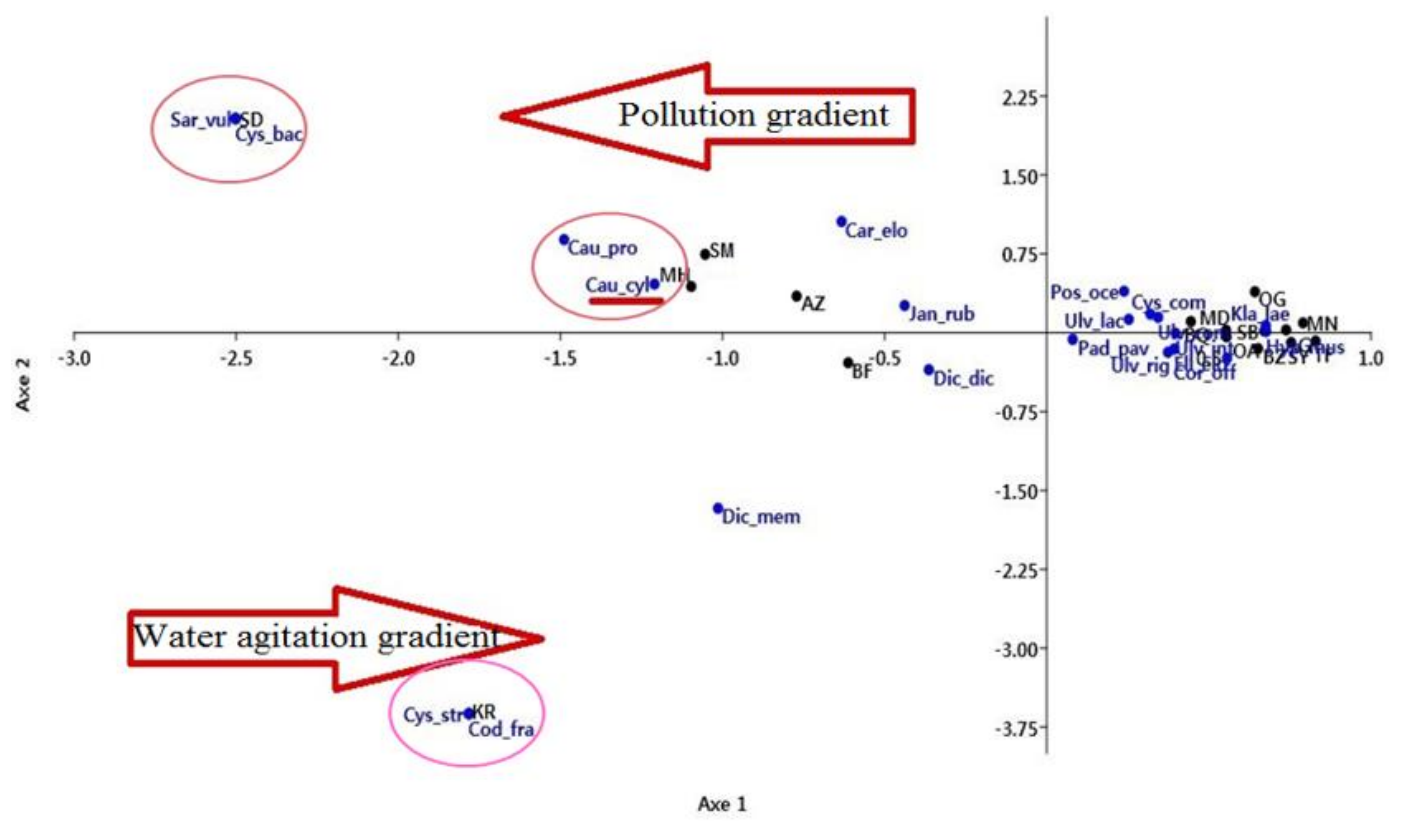

Figure 4. F1-F2 factorial plane of the different species distribution

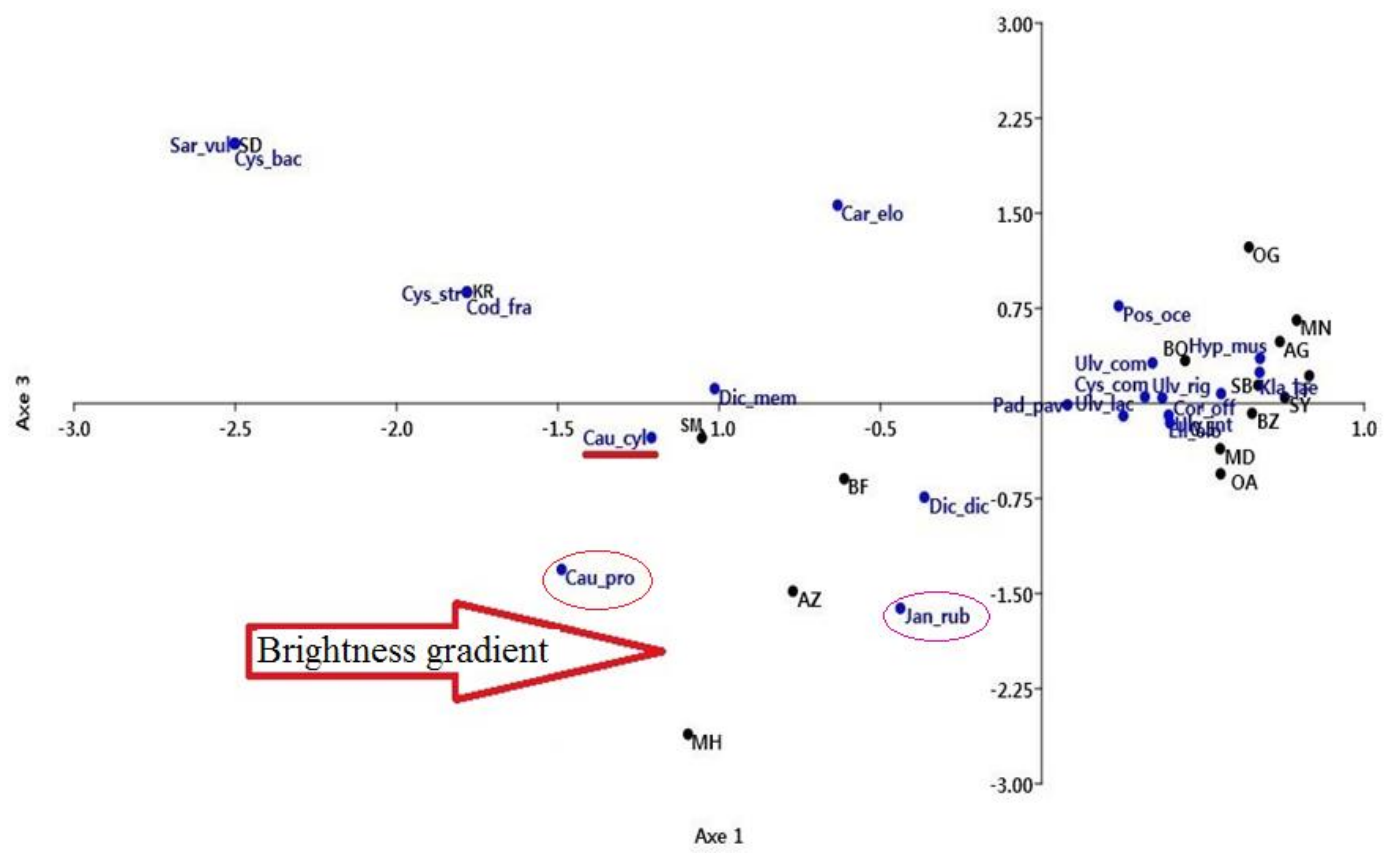

Figure 5. F1-F3 factorial plane of different species distribution

Ascending Hierarchical Classification (AHC)

The ascending hierarchical classification of the different sites (Figure 6), shows a gradient of invasion by C. cylindracea, highlighting two groups, G1 describing the sites most affected by the invasion of this invasive species, as well as group G2 presenting the sites least affected by the spread of this aggressive taxon.

The hierarchical classification of the 16 stations (Figure 7) allows us to identify two main groups corresponding to the following species assembling: G1: the invasive species C. cylindracea; G2: accompanying species (listed).
The second group is subdivided into two subgroups G2' and G2', the first (G2') contains species, which are represented in 1 to 4 sites. The second subgroup (G2'') adequately explains the taxa that occur at 4 to 15 sites.

The two species located in the extremities are subjected to principal component analysis such as $C$. cylindracea and P. oceanica.

\section{Principal Component Analysis (PCA)}

To confirm our results, a PCA Principal Component Analysis is performed on both ends of the AHC in 
particular C. cylndreacea and Posidonia oceanica (Figures 8 and 9). On the other hand, the results of the PCA relating to $C$. cyclindracea (Figure 9) reveal a curve that reflects an ever-increasing and unlimited propagation affecting several observation stations, of which the most affected sites by this great change are Stidia and Salamandre.

Our species presents a strong invasive behavior gaining the western Algerian coast (Ghellai et al. 2020), of which it should be noted that this spread of the invasive taxon tends to monopolize the ecological niche of the endemic species $P$. oceanica, even the degradation of a symbolic and endemic ecosystem of the Mediterranean. Long-term interaction with invasive algae could deteriorate the structure of Posidonia meadows, decreasing their initial resistance to invasion due to potential competitive mechanisms between the two macrophytes (e.g. allelopathic effects) (Bernardeau- Esteller 2019).

The characterization of macroalgae and seagrass assemblages shows poor coverage for all species in the invasion area (Bentaallah et al. 2021). In a study area in the Adriatic Sea (Italy), a greater abundance of $C$. cylindracea on the sand and detrital substrates is recorded (Pierucci et al. 2019). This is confirmed by a recent study by Sghaier et al. (2015), along the Tunisian coast, indicating a very high presence of $C$. cylindracea on sandy substrates, as well as the places of rocks and $P$. oceanica meadows. The effect of this alga on benthic communities was described by Piazzi et al. (2016), highlighting some main direct and indirect factors affecting the spread of this taxon, many of which are still poorly understood. For example, the relevance of depth, water movement, herbivores and other invaders in the dispersal dynamics of this pest is still unclear (Pierucci et al. 2019). Whereas, these communities play a significant role as environmental indicators because they have different levels of sensitivity to pollution (Kelly et al. 2017).

The expansion process can be very long, showing that only with long-term follow-up studies coupled with better ecophysiological knowledge of $C$. cylindracea, and through manipulation experiments, it might be possible to better understand the key factors invasion of this species in the Mediterranean Sea (Ivesa et al. 2015; Montefalcone et al. 2015). Further studies of biological interest in particular are needed to assess the spread, rate of invasion and impact of this alga, which remarkably affects different areas, at different depths and substrates (Pierucci et al. 2019).

In any case, the conditions of great uncertainty and biological variability, suggest the need for up-to-date monitoring and mapping programs of coastal ecosystems in order to guarantee the survival of endemic species still living in the Mediterranean, and the protection of their marine biodiversity (Bentaallah et al. 2021), which needs to be monitored at different levels of the affected coastline in order to effectively limit its expansion to the detriment of existing algal diversity (Bachir et al. 2021).

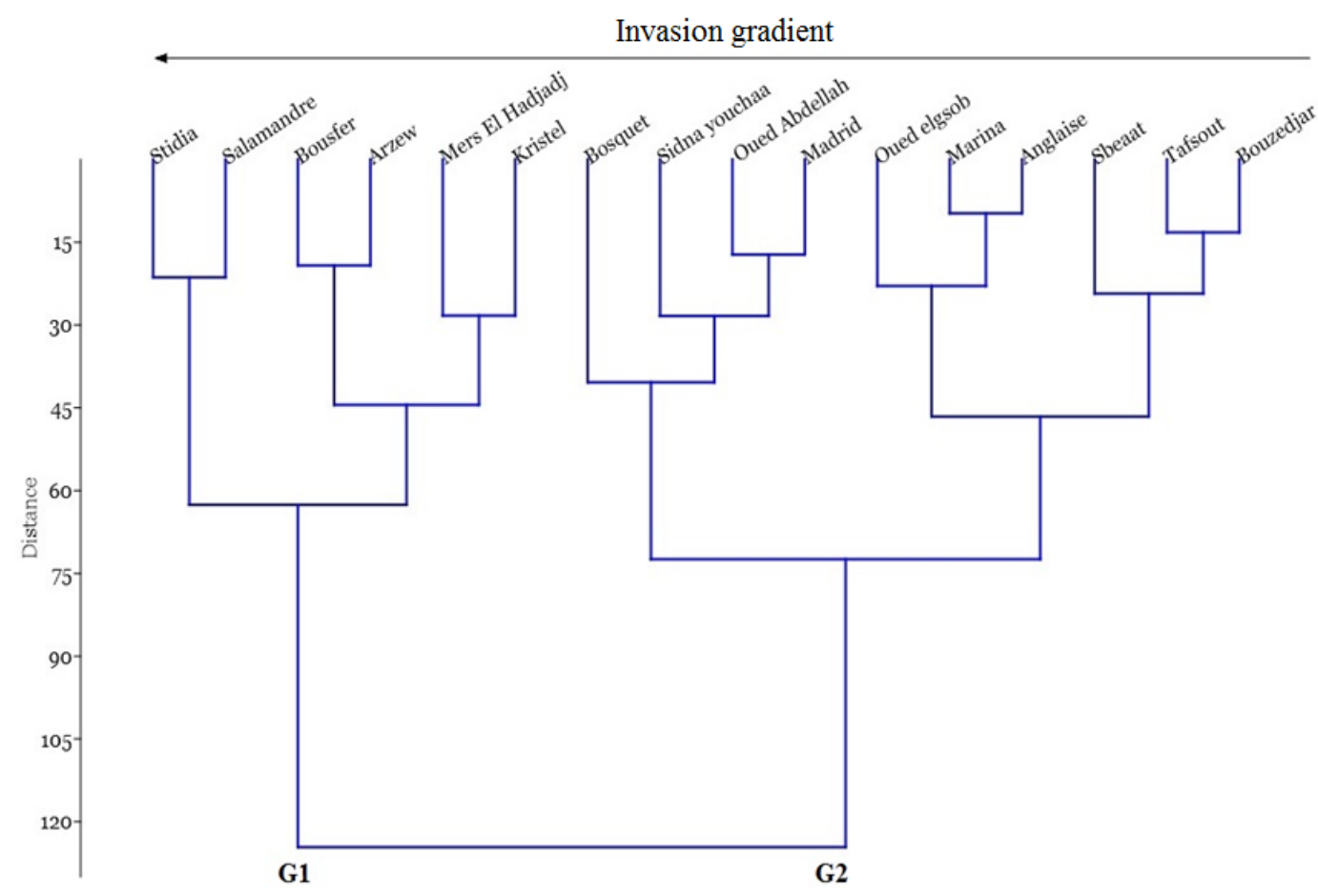

Figure 6. Ascending hierarchical classification of different stations 


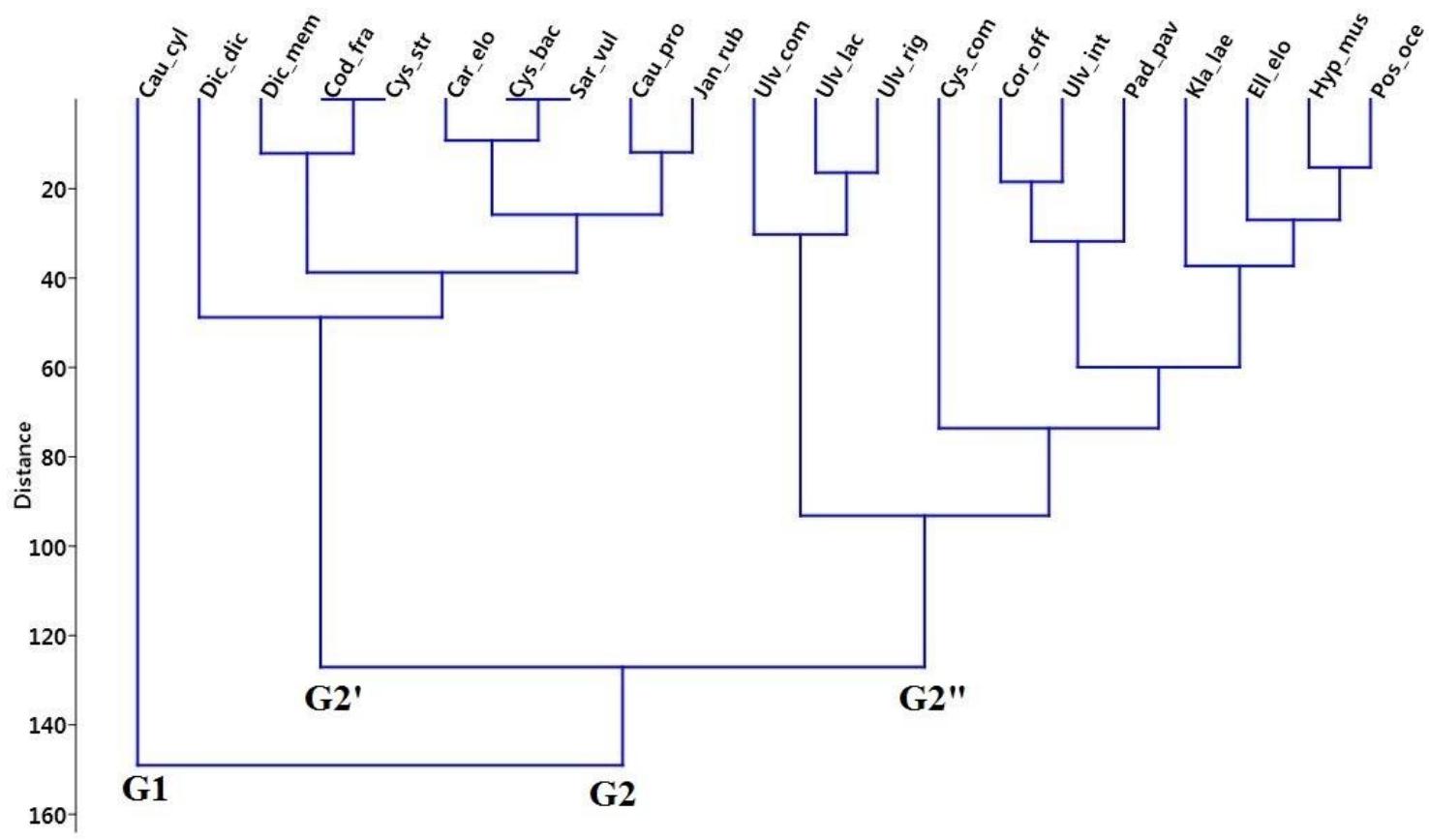

Figure 7. Ascending hierarchical classification of the various recorded species
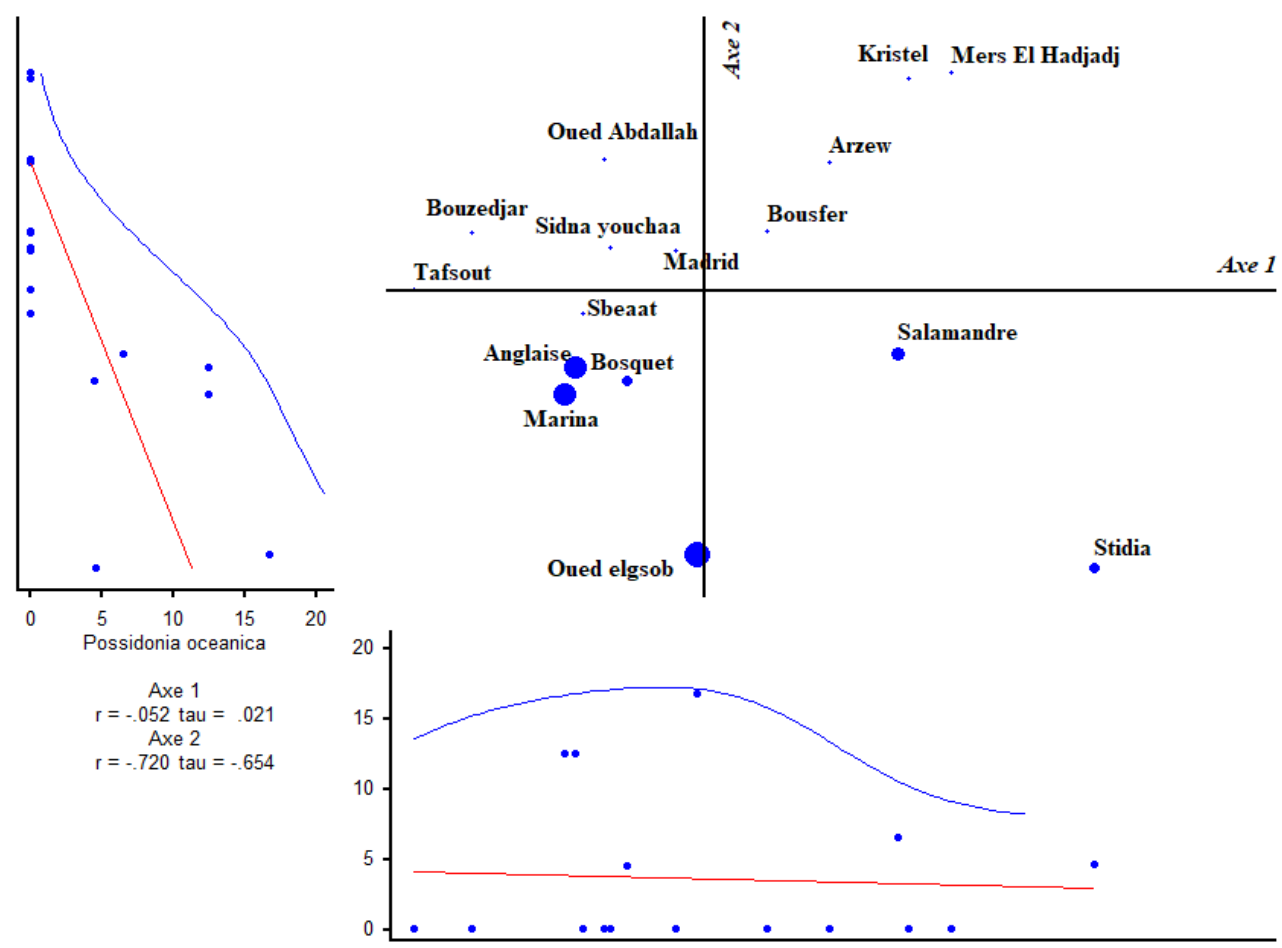

Figure 8. Plan F1-F2 of the PCA of the Ordination of Posidonia oceanica 


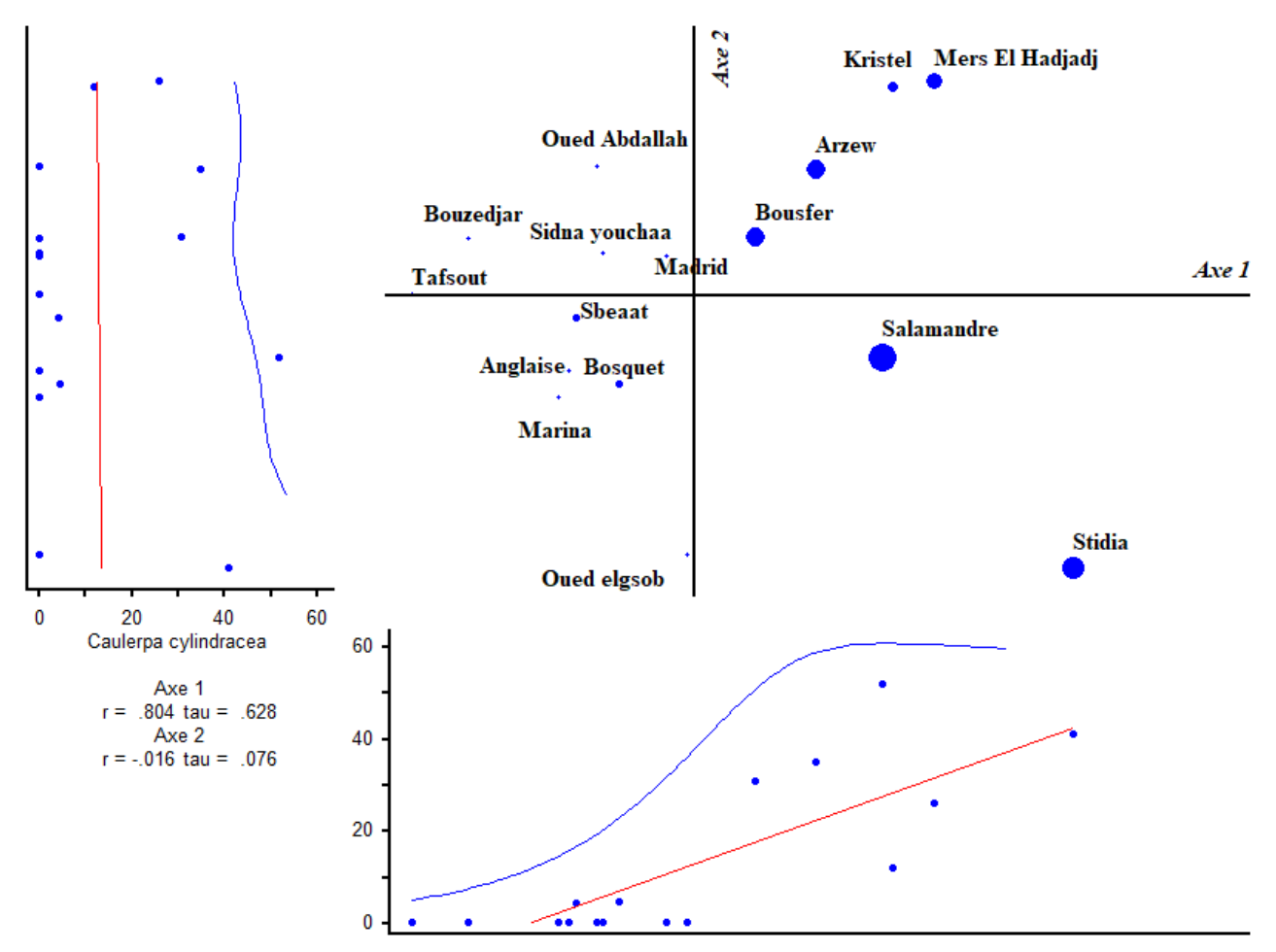

Figure 9. Plan F1-F2 of the PCA of the Ordination of Caulerpa cylindracea.

In conclusion, this study highlights the presence of $C$. cylindracea by prospecting sixteen selected sites on the Algerian west coast in order to estimate its impact on the distribution of other types of plants, even the marine phanerogam; Posidonia oceanica and macrophytes, of which it is noted that the sites strongly affected by the invasive taxon, present a low diversity of accompanying algae and suggest their replacement by $C$. cylindracea in particular for the station of Salamandre, Stidia, Arzew, Bousfer, Mers El Hadjadj, kristel, as well as for the Sbeaat and Bosquet sites, where the invasive species is beginning to settle. On the other hand, the stations representing the province of Tlemcen, Ain Témouchent and Chlef, hosting a floral procession rich in macrophytes, where the proportions of frequency, rate of establishment, and dominance of the various identified groups, are in balance.

The degree of danger of this biological pollution, associated with discharges of domestic wastewater, coming from sewerage networks without prior treatment, in certain observation sites, has caused changes and disturbances in these environments, and where the alga $C$. cylindracea has found facilities for colonizing large aquatic surfaces.

Responding to the challenges of mitigating this invasive alien species $C$. cylindracea, we aim; monitor the expansion of this taxon in order to prevent its spread in healthy environments, which is strongly recommended, to carefully monitor these expansions, and to slow them down through awareness-raising operations and the organization of tearing off by professional fishermen, boaters, amateurs, swimmers, to make them know the invasive species, and its effects on the marine ecosystem, in the case where areas occupied by the invasive specimen do not exceed one square meter, therefore the sites weakly affected with tourist potential are the first targets. The monitoring and mapping of the appearance of new colonies must be expressly reported to the services responsible for the protection of the environment and the coast.

\section{ACKNOWLEDGEMENTS}

We thank warmly Hamsas S, for her help in carrying out this work. We also wish to thank La Direction Générale de la Recherche Scientifique et du Développement Technologique (DGRST, Algeria) for the financial support of the study.

\section{REFERENCES}

Avila C, Núñez-Pons L, Moles J. 2018. From the tropics to the poles: Chemical defensive strategies in sea slugs (Mollusca: Heterobranchia). In: Puglisi MP, Becerro MA (eds) Chemical Ecology: The Ecological Impacts of Marine Natural Products. CRC Press, Boca Raton, FL, USA. DOI: 10.1201/9780429453465-3.

Bachir Bouiadjra B, Taleb MZ, Marouf A, Youcef BM, Riadi H. 2010. First record of the invasive alga Caulerpa racemosa (Caulerpales, Chlorophyta) in the Gulf of Arzew (western Algeria). Aquat Invasion 5 (1): S97-S101. DOI: 10.3391/ai.2010.5.S1.020.

Bachir Bouiadjra B. 2012. L'étude de la Flore Algale Benthique et les Impacts de ses Espèces Invasives Devant la Côte Mostaganemoise. [Thesis]. Université Abdelhamid Ibn Badis, Mostaganem, Algérie.

Bachir Bouiadjra B, Ghellai M, Daoudi M, Behmene IE, Bachir BMEA. 2021. Impacts of the invasive species Caulerpa cylindracea Sonder, 1845 on the algae flora of the west coast of Algeria. Biodivers Data J 9: e64535. DOI: 10.3897/BDJ.9.e64535. 
Balestri E, Vallerini F, Menicagli V, Barnaba S, Lardicci C. 2018. Biotic resistance and vegetative propagule pressure co-regulate the invasion success of a marine clonal macrophyte. Sci Rep 8 (1): 16621. DOI: 10.1038/s41598-018-35015-0.

Belkacemi L, Belalia M, Djendara AC, Bouhadda Y. 2020. Antioxidant and antibacterial activities and identification of bioactive compounds of various extracts of Caulerpa racemosa from Algerian coast. Asian Pac J Trop Biomed 10 (2): 87-94. DOI: 10.4103/2221-1691.275423.

Bentaallah MEA, Kerfouf A. 2013. Prolifération de l'algue Caulerpa racemosa dans les écosystèmes littoraux de l'Algérie : état des lieux et des connaissances. Physio-Géo Géographie Physique et Environnement 7 : 157-164. DOI: 10.4000/physio-geo.3238. [French]

Bentaallah MEA, Taibib NE, Cantasano N. 2021. Additional new records of Caulerpa cylindracea Sonder 1845, along the West Algerian Coasts. Indian J Geo Mar Sci 50 (2): 122-129.

Bernardeau-esteller J, Marín-Guirao L, Evidence for the long-term resistance of Posidonia oceanica meadows to Caulerpa cylindracea invasion. Aquat Bot 160: 103167. DOI: 10.1016/j.aquabot.2019.103167.

Blunt JW, Carroll AR, Copp BR, Davis RA, Keyzers RA, Prinsep MR 2018. Marine natural products. Nat Prod Rep 35: 8-53. DOI: 10.1039/c7np00052a

Boudouresque CF. 1971. Méthodes d'étude Qualitative et Quantitative du Benthos (en Particulier du Phytobenthos). Thetys 3 (1): 79-104. [French]

Cariou N, Chery A, Jousseaume M, Richir J, Lejeune P, Gobert S. 2013. L'indice paysager Caulerpa racemosa "I.Ca.r". In: Ifremer AFB (eds). Cartographie des Habitats Marins Benthiques: de L'acquisition à la Restitution. Actes de Colloque, Brest, France. [French]

Carroll AR, Copp BR, Davis RA, Keyzers RA, Prinsep MR. 2019. Marine natural products. Nat Prod Rep 36: 122-173. DOI: 10.1039/C8NP00092A.

Chabane K. 2019. Fonctionnement et Diversité d'un Ecosystème à Macroalgue de Substrat Rocheux de la Région d'Alger. [Thesis]. Université des Sciences et de la Technologie Houari Boumediene USTHB-Alger, Algérie.

Chahrour, F. 2013. Etude de la Vitalité des Herbiers à Posidonia oceanica (L). Delile de la Côte Occidentale Algérienne. [Thesis]. Université Ahmed Benbella 1, Oran, Algérie.

Frontier S, Pichode-Viale D. 1991. Ecosystèmes: Structure et Fonctionnement, Evolution. Collection Ecologie, Masson ed. www.agris.fao.org.

Ghellai M. 2021. L'expansion, le Contrôle et le Suivi de l'algue Marine Invasive: Caulerpa racemosa var. cylindracea (Forsskal) J.Agardh; Devant la Côte Ouest Algérienne. [Thesis]. Université Abdelhamid Ibn Badis, Mostaganem, Algérie.

Ghellai M, Bachir BB Bachir BMEA, Sahih F, Mahmoudi K. 2020 Mineral balance of an invasive alga Caulerpa racemosa var. cylindracea on the coast west of Algeria. Plant Arch 20 (2): 4627 4632

Gobert S, Richir J. 2019. Des indices pour la définition de l'état des masses d'eau en milieu marin: Mises au point, applications et aide à la gestion. Geo Ecol Trop 43 (3): 353-364

Gribben PE, Thomas T, Pusceddu A, Bonechi L, Bianchelli S, Buschi E. 2018. Below-ground processes control the success of an invasive seaweed. J Ecol 106 (5): 2082-2095. DOI: 10.1111/1365-2745.12966.

Hussein KB, Bensahla TL. 2019. First record of invasive green algae Caulerpa racemosa var. cylindracea in Oran Bay (Western Algeria). Indian J Geo Mar Sci 48 (3): 335-342.

Ivesa L, Djakovac T, Devescovi M. 2015. Spreading patterns of the invasive Caulerpa cylindracea Sonder along the west istrian coast (northern Adriatic Sea, Croatia). Mar Environ Res 107: 1-7. DOI: 10.1016/j.marenvres.2015.03.008.
Kalasariya H, Patel V, Patel R, Patel N, Rathwa S. 2020. Seaweeds diversity study of selected Beyt dwarka coast in Gujarat, India. Intl J Bot Stud 5 (1): 141-145.

Kelly C, Mitrasetia T, Sugardjito J. 2017. An assessment of a tropical urban stream using benthic macroinvertebrates as a bio-indicator in Muara Angke, Jakarta, Indonesia. Bonorowo Wetl 7 (2): 65-73. DOI: 10.13057/bonorowo/w070202.

Khalid S, Abbas M, Saeed F, Bader-Ul-Ain H, Suleria HAR, 2018. Therapeutic potential of seaweed bioactive compounds. In: Maiti S (eds). Seaweed Biomaterials. IntechOpen, London, UK. DOI: 10.5772/intechopen.74060.

Kumar JGS, Umamaheswari S, Kavimani S, Ilavarasan R. 2019. Pharmacological potential of green algae Caulerpa: A review. Intl J Pharm Sci Res 10 (3): 1014-1024. DOI: 10.13040/IJPSR.0975-8232.

Manconi R, Padiglia A, Padedda BM, Pronzato R. 2020. Invasive green algae in a western Mediterranean Marine Protected Area: Interaction of photophilous sponges with Caulerpa cylindracea. J Mar Biol Assoc U K 100 (3): 361-373. DOI: 10.1017/S0025315420000193.

Montefalcone M, Morri C, Parravicini V, Bianchi CN. 2015. A tale of two invaders: Divergent spreading kinetics of the alien green algae Caulerpa taxifolia and Caulerpa cylindracea. Biol Invasions 17: 2717-2728. DOI: 10.1007/s10530-015-0908-1

Oucif H, 2018. Valorisation des Algues de la Côte Ouest algérienne: Potentiel Antioxydant et Hormonal. [Thesis]. Université Ahmed Benbella 1, Oran, Algérie.

Oucif H, Adjout R, Sebahi R, Boukortt FE, Ali MI, Abi ASMEA. 2017. Comparison of in vitro antioxidant activity of some selected seaweeds from Algerian west coast. Afr J Biotechnol 16 (26): 1474-1480. DOI: 10.5897/AJB2017.16043

Piazzi L, Balata D, Bulleri F, Gennaro P, Ceccherelli G. 2016. The invasion of Caulerpa cylindracea in the Mediterranean: The known, the unknown and the knowable. Mar Biol 163 (7): 161. DOI: 10.1007/s00227-016-2937-4.

Pierucci A, de La Fuente CGR, Chiantore M. 2019. A new record of the invasive seaweed Caulerpa cylindracea Sonder in the South Adriatic Sea. Heliyon 5: e02449. DOI: 10.1016/j.heliyon.2019.e02449

Puglisi MP, Becerro MA. 2018. Chemical Ecology: The Ecological Impacts of Marine Natural Products. CRC Press, Boca Raton, FL, USA. DOI: 10.1201/9780429453465.

Ragunathan V, Pandurangan J, Ramakrishnan T. 2019. Gas chromatographymass spectrometry analysis of methanol extracts from marine red seaweed Gracilaria corticata. Pharmacog J 11 (3): 547554. DOI: $10.5530 / \mathrm{pj} .2019 .11 .87$.

Rizzo L, Pusceddu A, Bianchelli S, Fraschetti S. 2020. Potentially combined effect of the invasive seaweed Caulerpa cylindracea (Sonder) and sediment deposition rates on organic matter and meiofaunal assemblages. Mar Environ Res 159 (2): 104966. DOI: 10.1016/j.marenvres.2020.104966.

Sghaier YR, Zakhama-sraieb R, Mouelhi S, Vazquez M, Valle C, Ramosespla A. 2015. Review of alien marine macrophytes in Tunisia. Mediterr Mar Sci 17 (1): 109-123. DOI: 10.12681/mms.1366.

Shannon CE, Weaver W. 1949. The mathematical theory of communication. University of Illinois Press, Urbana, IL.

Simboura N, Zenetos A. 2002. Benthic indicators to use in ecological quality classification of Mediterranean soft bottoms marine ecosystems, including a new biotic index. Mediterr Mar Sci 3/2: 77111. DOI: $10.12681 / \mathrm{mms} .249$.

Tamburello L, Maggi E, Benedetti-cecchi L, Bellistri G, Rattray AJ, Ravaglioli C. 2015. Variation in the impact of non-native seaweeds along gradients of habitat degradation: A meta-analysis and an experimental test. Oikos 124: 1121-1131. DOI: 10.1111/oik.02197. 